BOOK REVIEW

RECENSIONE

\title{
Atlas of SPECT-CT
}

\author{
S. Fanti • M. Farsad $\cdot$ L. Mansi
}

\section{Springer-Verlag, Berlin Heidelberg, 2011 \\ ISBN: 978-3-642-15725-7 \\ e-ISBN: 978-3-642-15726-4 \\ DOI: $10.1007 / 978-3-642-15726-4$}

Published online: e9 August 2012

C) Springer-Verlag 2012

This book, planned and intended as an atlas, aims to offer the reader know-how and up-to-date knowledge on state of the art applications in nuclear medicine, i.e. single photon emission computed tomography (SPECT)-computed tomography (CT).

SPECT-CT has earned a special place in daily clinical practice not only in oncology (nowadays it offers a clear indicator of disease, even when other imaging modalities can be deceptive or even misleading), but also in other different clinical settings such as cardiology, endocrinology and internal medicine.

A host of experts based on their daily practice using this hybrid imaging system have poured informative text augmented by a large amount of explicative images.

Text pages are limited to the essential concepts necessary to undertand how the system works, and to the explanations necessary to understand what is presented in the images, enriched by a more or less long list of references, suggested readings, and tables.

Images are sorted by case-presentation with short captions and teaching-point boxes at the end of each case presentation. The authors take it for granted that the images are fully understood by the reader: since a large number of them are rather small and lack arrows to pin-pointing the region of interest, this is not always the case.

There are a few incorrect refences to figures, pages and images. Sometimes, acronyms are not explained. Apart from these comments this atlas-book should be useful to all those who want to gain knowledge and insight into this fascinating new diagnostic tool.
Questo volume, pensato e pianificato come un atlante, vuole offrire al lettore cognizioni tecniche e conoscenze aggiornate sulle applicazioni dello stato dell'arte in medicina nucleare e cioè sulla single photon emission computed tomography (SPECT)-tomografia computerizzata (CT).

La SPECT-CT ha conquistato un posto speciale nella attività clinica quotidiana, non solo in oncologia (offre infatti un chiaro indicatore della presenza di malattia, anche quando oltre metodiche di studio per immagine possono essere ingannevoli, se non addirittura fuorvianti), ma anche in altri campi clinici come cardiologia, endocrinologia e medicina interna.

Una schiera di esperti, basandosi sulla propria attività quotidiana nell'uso di questo sistema ibrido per immagini, l'ha riversata in un testo informativo, implementato da una grande quantità di immagini esplicative.

Le pagine di testo sono limitate ai concetti essenziali per la comprensione del funzionamento del sistema ed alle spiegazioni necessarie per capire ciò che è presentato nelle immagini, il tutto arricchito da elenchi più o meno lunghi di riferimenti bibliografici, letture suggerite e tabelle.

Le immagini sono selezionate sulla base della presentazione di casi, corredati da succinte didascalie e tabelle che ne riassumono i punti di interesse e di apprendimento alla fine di ogni presentazione. Gli autori danno per scontato che le immagini siano ben comprese dal lettore; ciò però non è sempre il caso, dal momento che una gran quantità di esse sono di dimensioni piuttosto piccole e mancano di frecce che ne indichino le regioni di interesse.

Da notare che vi sono alcuni riferimenti non corretti a figure, pagine ed immagini e che alcuni acronimi non sono esplicitati. Non tenendo conto di questi commenti, questo testo-atlante sarà utile a tutti coloro che desiderino conoscere e approfondire questo nuovo ed affascinante strumento diagnostico. 